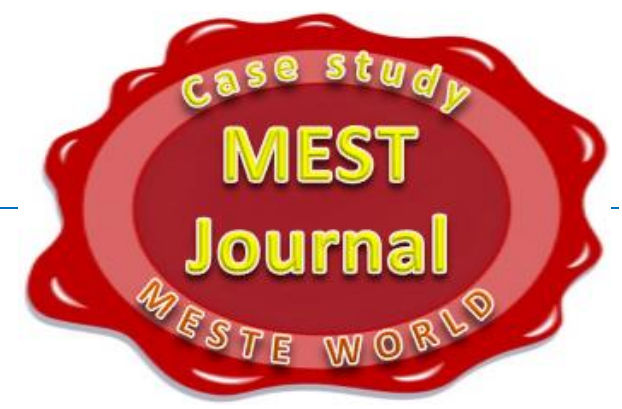

\title{
LEADERSHIP SKILLS OF THE YOUNG PROFESSIONALS IN INDUSTRY AND OTHER INSTITUTIONS - A CASE STUDY FOR MASTER STUDENTS
}

\section{Nevenka Kiteva Rogleva}

Ss Cyril and Methodius University, Faculty of Electrical Engineering and Information Technologies, Skopje, Republic of Macedonia

\section{Sonja Gegovska-Zajkova}

Ss Cyril and Methodius University, Faculty of Electrical Engineering and Information Technologies, Skopje, Republic of Macedonia

\section{Vangel Fustik}

Ss Cyril and Methodius University, Faculty of Electrical Engineering and Information Technologies, Skopje, Republic of Macedonia

\section{(C) MESTE NGO}

JEL category: A2, A23, 123

\begin{abstract}
Current conditions in the economies in transition, affected by the globalization of the business, focus on social awareness for improvement and development of the professional soft skills. While one part of the managers faces with bad forecasts for the success of the company, where they work, the rest of them, quite confidently and reliably recognize all possibilities, even in critical conditions and fail to cope with the challenges and to express their superiority above others. These professionals, so successful in modern organizations, are making the valuable asset of the companies that are leading. These managers possessing appropriate soft skills become the corner stone of organizational business success.
\end{abstract}

This paper deals with the self-awareness of the young professionals on master study curricula Project management at Faculty of Electrical Engineering and IT in Skopje, Republic of Macedonia. The survey includes was conndusted in a period of 5 years and the number of respondents is about hundred. The analysis summarized the results of a such survey concerning the managerial role and focus in detail in the responses pertaining to the interpersonal roles and leadership capability. The results could be used

Address of the author:

Nevenka Kiteva Rogleva

㭋"nniteva@feit.ukim.edu.mk as a basis for further investigations of the nedeed skills for young professionals in industry for improvement of the effectiveness of their academic knowledge in engineering business practice. 
Keywords: managerial role, leadership skills, professional competences, master students, engineering and project management

\section{INTRODUCTION}

Current conditions in the economies in transition, affected by the globalization of the business, focus on social awareness for improvement and development of the professional soft skills. Today beyond the knowledge and technical skills, employers are looking for business awareness and capacity for self-esteem and selfmanagement in job applicants (Atfield \& Purcell, 2010).

Brown and Hesketh (2004) assume that personal qualities and attributes such as interpersonal skills and time-management, together with organisational skills and efficiently problem solving capacity are important for the chief managers in order to evaluate their employees. It is therefore necessary for graduate students or young managers to be able to communicate, negotiate, and work as a team, to have informational and decision making capacity and also ability to recognize all possibilities, even in critical conditions and to cope with the challenges. Only these kind of professionals are making the valuable asset of the companies that are working for.

Professionals and managers possessing appropriate soft skills become the cornerstone of organizational business success.

What about the young professionals and gradute students in small and developing countries like Republic of Macedonia? What kind of skills do they possess? Are they aware of that? How they develop and improve their skills?

Asking to self-esteem the knowledge and skills they possess, graduate students and young professionals from business organizations, did not come with facts, but compare themselves with the abilities of some reference groups. Relevant in the case of students, are skilled students or other members of their peer group, teachers or trainers. For the emloyees essential are senior and project managers with such abilities and attributes they are familiar to. It is, also, important to have in mind that self-rating or self-esteem is subjective and highly context-influenced.
Respondents also mention that universities attempt to incorporate skills development into their teaching and learning provisions. University and high schools in developed countries and European Union have already included huge modifications to existing course content, through embedding the development of particular skills within the wider academic content, the development of new courses and teaching methods, and the provision of stand-alone skills courses offered either at the departmental level or on a university-wide basis (Mason, Williams, \& Cranmer, 2006, p. 4). That is the reason why master students have great expectation for enhancing or modifying their abilities and capacities through professional work and education.

In order to develop and/or to improve the ability to work on a projects, to communicate, negotiate, to lead and make decisions, all respondents continue education on next level, master or doctoral degree. They assume that Project management course with implementation of new Information and Communication Technologies (ICT) in projects and in business also is one of the best options.

To obtain the personal characteristics of the managers, Mintzberg (1973, pp. 54-99) analyses managerial activities and responsibilities. He divided managerial role into three sections: interpersonal, informational and decisional. Every section was than subdivided into three subsections. Within the interpersonal section he defined manager role as a leader, person that motivate, innovate and make changes to achieve business goals; as figurehead, promoter of commitment between organization and stakeholders and liaison is manager that prefer communication and relationships between stakeholders (between company and its partners and clients).

Monitor, disseminator and advocate roles are part of the informational category. When managers are able to identify the needs, programs and services 
for company development they are classified as monitor.

Disseminator has competence to communicate effectively and to develop personal performance. They transmit the information from the outside to the company members, while advocate managers had working knowledge and transmit the date in opposite direction, from company to the clients or partners (outside of the company).

The final decisional section includes managers as: changers, disturbance handler, resource allocator and negotiator.

Managers that are willing to develop strategies, design plans and looking for new opportunities are named as changers or entrepreneurs. Disturbance Handler are forced to resolve problems/conflicts and to find new alternatives. They are named as resource allocator if they develop basic principles of company planning, manage times, develop budgets or design personnel plans. If managers are involved in major or local negotiations and have ability for problem solving and decision making they are classified as negotiators.

It is important to mention that all managerial roles (Mintzberg, 1973, p. 58), are integrated and could not be isolated from each other.

This paper summarize the results of a survey concerning the managerial role and focus in detail in the responses pertaining to interpersonal roles and leadership capability.

Section 2 of this paper examines the leadership trends in organization with a view to define academic leadership and evaluate the leadership potential of post-graduate candidates.

The results of the survey are presented in section 3. Conclusion and remarks from the survey are given in section 4 .

\section{LEADERSHIP TRENDS LITERATURE REVEIW}

By the end of the 20th century Burns (1978) and House (1977) suggested that leadership could be understood as transformational or charismatic leadership. Transformational leaders were described as "inspirational, intellectually stimulating, challenging, visionary, development oriented and determined to maximize performance" (Avolio \& Bass, 2004). This leadership style focuses more on the exchange between managers and associates through constructive and corrective behaviors, described as contingent reward, and management by exception, respectively (Avolio \& Bass, 2002; 2004). What defines an effective leader or effective leadership behavior in one context may be completely different from what defines an effective leader in another setting (Fielder \& Chemers, 1974).

The results from the large scale research project involving hundreds of business leaders in four different countries - Canada, the United States, England and China identified three core domains: character, capabilities and commitment, describing who the leaders are and what leaders do (Gandz, Crossan, Seijts, \& Stephenson, 2010).

Leaders are forced to make changes in development of organizational strategies and ways of performing its business. Economy conditions impose leaders not only to adapt to changes in the environment but also to create change. However, academic leaders today must be able to demonstrate teamwork and communication capabilities beyond the confines of their own faculty or academic discipline. The organizations need leaders who are able to manage the processes of change that are one step ahead of others who think long term and who understand that maintaining the status quo is detrimental in terms of turbulent change and environments.

Such managers are leaders; they lead organizations towards achieving superior performance. Undoubtedly leadership has become a critical factor in the success of modern companies and most expensive resource in any company. Human Resource departments in companies are facing the problem how to find the best managers for key managerial positions. 


\section{RESEARCH METHODS AND ANALAYSIS}

Although more present interest in the application of leadership, empirical research on the topic of leadership among young professionals in industry and other organizations in Republic of Macedonia are quite rare and for that reason a survey was conducted each year, from 2009 to 2014 .

Almost hundred of young managers who continued their education on master studies in the field of Project Management - Leadership, management and communication have filled-out a particular questionnaire.

The group consists of female and male students, at the age of 24-40 years. Most of them have had working experience from 1-10 years and only $10 \%$ continue the education on masters after graduation.

The questionnaire included twelve questions divided into three sections. Section 1 collected students' perceptions of their development of interpersonal skills and abilities in recent years. Sections 2 collected similar data in relation to their informational capacity and Section 3 required data or comments on any aspect of decision making process. Section 1 was divided on three subsections. The first one refers to managerial role as a leader, the second one as a figurehead and third one as a liaison.

Students were asked to define their level of competence, their strengths and weaknesses in relation to a range of skills on a scale of '1 to 9'. ' 1 ' means that their skills are at low level, ' 5 ' that their skills are good and ' 9 ' that they have excellent managerial skills. They completed the questianary independently and anonymous. An analysis was performed and results are graficaly shown on fig.1-fig.9.

According to the results, 15 of 97 surveyed participates (15\%), have excellent skills as figurehead, $20 \%$ have low skills and most of them, about $50 \%$ have good managerial skills as figurehead, as it is shown in the Fig.1. Two of 97 respondents though they didn't have ability to perform symbolic duties of a legal or social nature, if they are head of organization.

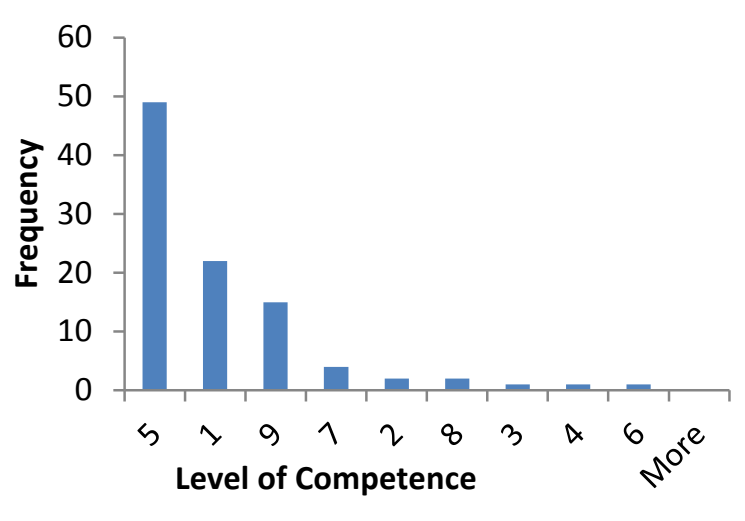

Fig. 1 Figurehead level of competence

Almost half of students think they have excelent $(43 \%)$ or good $(33 \%)$ competence as a liasion (Fig.2). They are able to communicate and to connect with experts outside the company in order to fullfill business startegy.

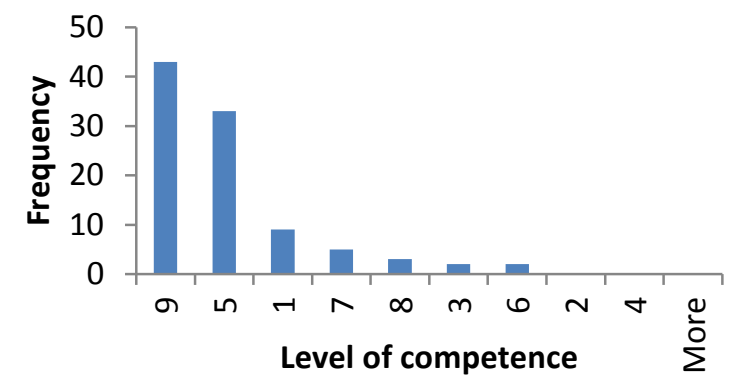

Fig. 2 Students ability as a liaison

The survey includes young managers from different types of companies likes banks, schools, private or pablic companies even employees in goverment or governmental bodies and agencies. How they score their ability as a leader is shown in Fig.3.

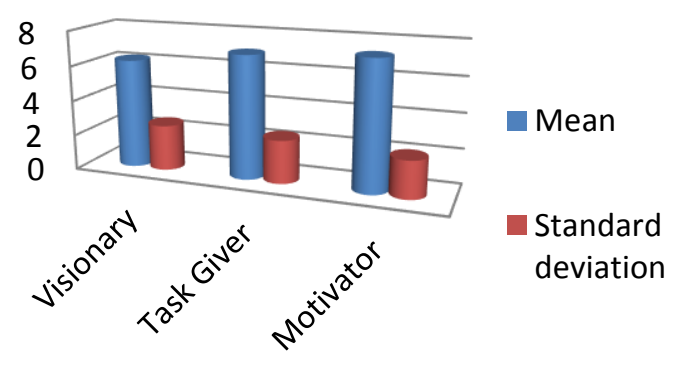

Fig. 3 Mean and Standard Deviation for Sample (Type of leader) 
The results show that most of the respondents think they had ability to be a leader and have high skills as task giver (53\%) and visionary (49\%) (Fig.4). The other half of the respondents define good or poor ability to motivate, encourage inovative prformance and establish mutual trust.

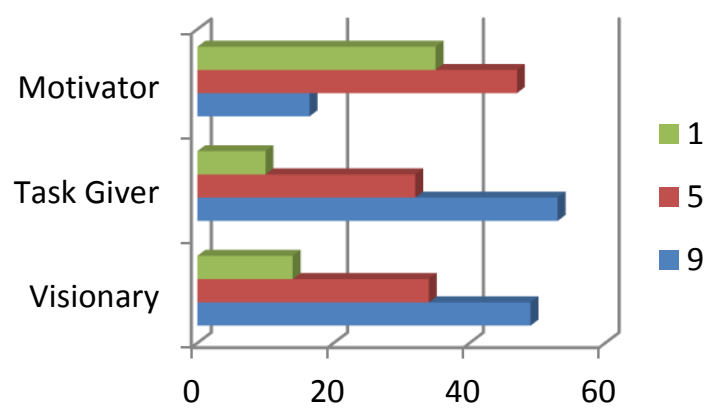

Fig. 4. Level of Competence - Leader

Respondents believe postgraduate course will enable them to develop certain skills, and half of them belive job experince will enable them to develop specialist knowledge.

This is a good indicator for the organizations, since it shows increasing awareness of the usefulness of postgraduate studies and special leadership trainings for improving creative thinking, motivation and aplaying quality standards and concepts.

Section 2 gives a perception in relation to respondents informational capacity (fig. 5). The results show that more than $50 \%$ of respondents have excelent disseminator ability, $48 \%$ had ability to understand informal organisation, to evaluate oppotunities, to monitor, and only $17 \%$ belived that can act like advocate.

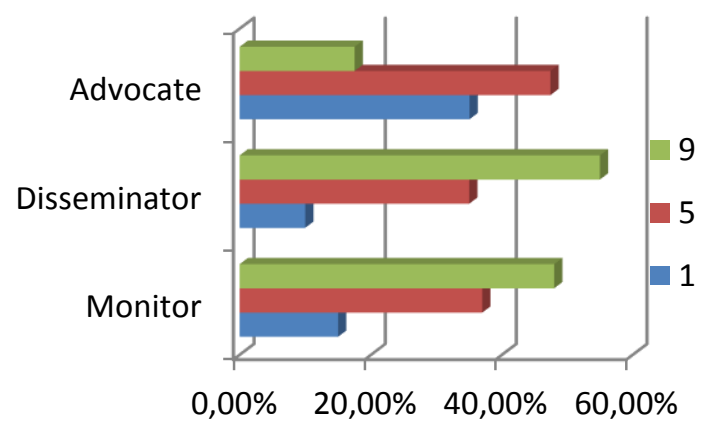

Fig. 5. Informational Roles
Mean and standard deviation for the sample is shown on fig. 5. Results show that respondents can easily assess the needs of institution, define programs, use them to evaluate opportunities, communicate (mean value for disseminator and monitor role of the manageres is almost the same) rather than to deal effectively with mass media and have working knowledge of political processess (low mean value for advocate).

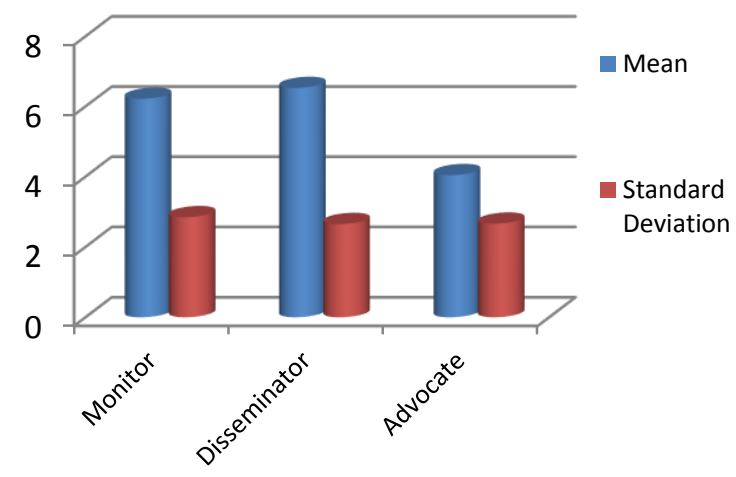

Fig. 6. Mean and Standard Deviation for Sample

The final set of questions concerne the decisional roles of young manageres and graduate students. The results at Fig. 7 show that $60 \%$ of respondents are able to identify problems and work to resolve them.

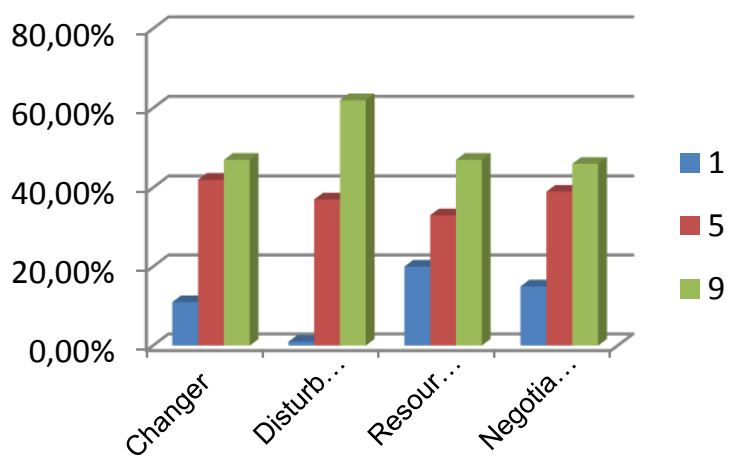

Fig. 7. Level of Competence - Leader

More than half respondents (50-60\%), are familiar with decisional role. Mean value for disturbance handler is the bigest and for resource allocator and negotiotor the small one as it is shown in Fig. 8. 


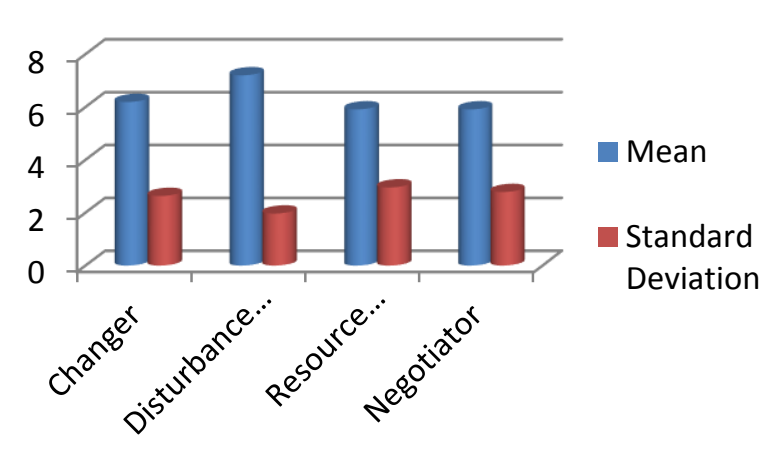

Fig. 8. Mean and Standard Deviation for Sample

\subsection{Analysis of the results}

The main objective of the survey was to examine young managers perception for their ability and skills. According to Mintzberg study (1973, p. 130), managers had common roles but with different emphasis. He postulated that managers at lower levels tend to spend more time as disturbance handlers and negotiators and less time in the figurehead role. He also named two grups of managers - informational and decisional. Although Mintzburg classified managerial roles as changer, negotiator, disturbance handler and resource handler in one group, analysis of the respondents' answers shows another (different) situation.

The results, as it is shown on Table 1, present the means and standard deviations for the sample of almost hundred master students on Project management study curricula.

According the means value, students can be devides into two groups. First formed group, with low mean value, consists of figurehead, changer and resource allocator. Figurehead functions seems relevant to changer function because this kind of managers contacts with chief executives from other company. changer role is to distribute the information externally (Shapira \& Dunbar, 1980).

The second group, with mean value $>6$ consists of leader, concern with motivation and inovation in company, liaison - for building up an external informational system, negotiator, disturbance handler and monitor role.
Table 1. Means and standard deviation for mangerial roles

\begin{tabular}{|l|l|l|}
\hline Managerial roles & Mean & $\begin{array}{l}\text { Standard } \\
\text { deviation }\end{array}$ \\
\hline Visionary & 6.237113 & 2.597167 \\
\hline Task Giver & 7.010309 & 2.451593 \\
\hline Motivator & 7.309278 & 2.127992 \\
\hline Figurehead & 4.752577 & 2.626115 \\
\hline Liaison & 6.56701 & 2.621653 \\
\hline Monitor & 6.216495 & 2.843951 \\
\hline Disseminator & 6.525773 & 2.65005 \\
\hline Advocate & 4.041237 & 2.66113 \\
\hline Changer & 6.185567 & 2.631262 \\
\hline $\begin{array}{l}\text { Disturbance } \\
\text { Handler }\end{array}$ & 7.195876 & 1.966592 \\
\hline $\begin{array}{l}\text { Resource } \\
\text { Allocator }\end{array}$ & 5.907216 & 2.954807 \\
\hline Negotiator & 5.907216 & 2.780447 \\
\hline
\end{tabular}

In 1964, in his study, Sayles notes that monitor phase always occure after solution of a problem so is better to be grouped with decisional roles then with informational as Mintzberg done in his study later (1973).

In order to correlate the managerial roles and to determine the distances among them, intercorrelation coeficients were calculated and shown on Fig. 9 managerial roles.

According to Fig. 9, first three managerial roles: visionary, task giver and motivator which define a leader role, are not correlated to each other. The correlation coefficient is about 0.1 . It is assumed that correlation between them is too low, because of respondent's subjectivity and because they try to find themselves in every managerial role.

If the lower bound for the value of correlation coefficient is asumed to be 0.5 than visionary as a manager role is correlated with monitor and changer/ entrepreneurial.

The question is: Are they really connected?

It seems that changer will be familiar with visionary role only if he knows how to recognize momentum during his business mission to find out new and better opportunities for the company. 


\begin{tabular}{|c|c|c|c|c|c|c|c|c|c|c|c|c|}
\hline & Visiona & ask Giv I & Motivat I & Figurel & I Liaison & Monitc & Dissel & I Advoc & Chans & ( Distu & Reso & Negol \\
\hline Visionary & 1.00 & & & & & & & & & & & \\
\hline Task Give & 0.11 & 1.00 & & & & & & & & & & \\
\hline Motivator & -0.07 & 0.31 & 1.00 & & & & & & & & & \\
\hline Figurehec & -0.09 & 0.13 & -0.08 & 1.00 & & & & & & & & \\
\hline Liaison & -0.06 & -0.02 & 0.11 & -0.12 & 1.00 & & & & & & & \\
\hline Monitor & 1.00 & 0.13 & -0.06 & -0.09 & -0.05 & 1.00 & & & & & & \\
\hline Dissemin & 0.11 & 0.88 & 0.27 & 0.14 & -0.02 & 0.10 & 1.00 & & & & & \\
\hline Advocate & -0.08 & 0.19 & 0.60 & 0.06 & -0.09 & -0.11 & 0.28 & 1.00 & & & & \\
\hline Changer & 0.95 & 0.20 & -0.02 & -0.04 & -0.05 & 0.96 & 0.15 & -0.09 & 1.00 & & & \\
\hline Disturban & 0.12 & 0.59 & 0.29 & 0.05 & 0.01 & 0.10 & 0.66 & 0.33 & 0.05 & 1.00 & & \\
\hline Resource & 0.22 & 0.22 & 0.16 & -0.09 & 0.04 & 0.20 & 0.25 & 0.19 & 0.13 & 0.11 & 1.00 & \\
\hline Negotiato & 0.34 & 0.22 & -0.01 & -0.04 & -0.07 & 0.34 & 0.17 & 0.06 & 0.27 & 0.13 & 0.28 & 1.00 \\
\hline
\end{tabular}

Fig. 9. Intercorelation of managerial roles

Task giver, disseminator and disturbance handler form the second correlated group (Fig. 9). Every one of them is trying to define standards, procedures, to use new technologies and to make effective communication inside and outside of the organization.

With this correlation coefficient managerial roles inside interpersonal, informational and decisional roles (Mintzberg, 1974) are not correlated.

If the lower bound for the value of correlation coefficient is asumed to be 0.25 , then task giver and motivator are correlated and form group leader. That means second group will be expanded with monitor and also with negotiator, correlated to resource allocator and changer. Now the results are almost the same as Mintzberg assumption for managerial roles.

For future data analysis and graphic presentation of the results Guttman and Lingoes Small Sample Analysis (SSA) is considered. The resulting clusters may be found to be somewhat interrelated, but considering the actual nature of the data in the survey, these clusters will probably more closely mirror the data than would the factors derived from the more familiar factor analytic technique with its more stringent metric assumptions (Taylor, 1971). Interest in the data matrix will focus, on estimating the clustering of individual questionnaire items in creating indices of those items which will provide more reliable measures of leadership skills.

\section{CONCLUSIONS}

A lot of companies, even in the developed countries failed because of not skilled staff. Economy in transition and social conditions could be the reason for low level management competence. The awareness of the necessity to maintain-up and apply technical knowledge, skills and technique, should be an objective for the top managers in the age of New Economy.

The survey conducted to the master students at one Faculty of Engineering and Information Technologies in the Republic of Macedonia is one of the rare surveys of this kind in the field of management and leadership.

According to the survey results, we can conclude that most of the respondents are aware of the ability and skills they possess. Most of them already had job experience and are aware of the technical knowledge they possess. But they believe that university is the place where can develop and improve most of the managerial roles, especially informational.

Now on one side there are graduate and master students and their abilities, and on the other side business and industry leaders and universities.

What kind of skills and knowledge university offer and what leaders need?

What today business leaders need is to increase productivity while decreasing costs. They highlighted three kind of skills needed by job 
applicants: teamwork, communication and flexibility. Written and oral communication skills are very important in today's high-powered workplace, but employees must also be able to use modern technology to communicate.

Maybe it is time universities and high schools to develop new or to modify the study curriculum and context of the lectures according to business and industry needs.
We hope that such research, as it is already presented in this paper, could improve the selfawareness, integrity and needed competences of the young professionals at their engineering workplace for a more efficient and effective appliance of their respectable technical knowledge.

\section{WORKS CITED}

Avolio, B. J., \& Bass, B. (2002). Developing Potential across a Full Range of Leadership: Cases on Transactional and Transformational Leadership. New Jersey, NJ: LEA Publishers.

Avolio, B. J., \& Bass, B. (2004). Multifactor Leadership Questionnaire - 5X. 3rd Edition. Manual and Sampler Set. Mind Garden, Inc.

Brown, P., \& Hesketh, A. (2004) The Mismanagement of Talent-employability and jobs in the knowledge economy. Oxford: Oxford University Press. XXX 50001. (2011, 06 09).

Burns, J. M. (1978). Leadership. New York, NY: Harper and Row.

Fielder, F. E., \& Chemers, M. M. (1974). Leadership and effective management. Longman Higher Education (December 1974)

Gaby, A. \& Purcell, K. (2010). Graduate labour market supply and demand: Final year students' perceptions of the skills they have to offer and the skills employers seek. Working paper 4 Institute for Employment Research. University of Warwick

Gandz, J., Crossan, M., Seijts, G., \& Stephenson, C. (2010). Leadership on Trial: A Manifesto for Leadership Development. London, ON: Richard Ivey School of Business.

House, R. J. (1977). A 1976 theory of charismatic leadership. In J. Hunt and L. L. Larson (Eds.), Leadership: The cutting edge. Carbondale, IL: Southern Illinois University Press.

Mason, G., Williams, G. \& Cranmer, S. (2006). Employability Skills Initiatives in Higher Education: What Effects Do They Have On Graduate Labour Market Outcomes?. London: National Institute of Economic and Social Research.

Sayles, L.R. (1964). Managerial behavior. New York: Mc-Graw-hill, 1964

Shapira, Z. \& Dunbar R.L.M. (1980). Testing Mintzberg's managerial Roles Classification Using an In-Basket Simulation. Journal of applied Psychology 1980. 65(1), 87-95.

Taylor, J. C. (1971). An Empirical Examination of A Four-Factor Theory of Leadership Using Smallest Space Analysis. Organizational Behaviour and Human Performance. 6, 249-266

Received for publication:

Revision received:

Accepted for publication:
02.02.2014

05.06 .2014

23.06.2014 
How to cite this article?

Style - APA Sixth Edition

Kiteva Rogleva, N., Gegovska-Zajkova, S., \& Fustik, V. (2014, 07 15). Leadership skills of the young professionals in industry and other institutions - a case study for master students. (Z. Čekerevac, Ed.) MEST Journal, 2(2), 86-94. doi:10.12709/mest.02.02.02.09

\section{Style - Chicago Fifteenth Edition:}

Kiteva Rogleva, Nevenka, Sonja Gegovska-Zajkova, and Vangel Fustik. 2014. "Leadership skills of the young professionals in industry and other institutions - a case study for master students." Edited by Zoran Čekerevac. MEST Journal (MESTE) 2 (2): 86-94. doi:10.12709/mest.02.02.02.09.

Style - GOST Name Sort:

Kiteva Rogleva Nevenka, Gegovska-Zajkova Sonja and Fustik Vangel Leadership skills of the young professionals in industry and other institutions - a case study for master students [Journal] // MEST Journal / ed. Čekerevac Zoran. - Belgrade : MESTE, 07 15, 2014. - 2 : Vol. 2. - pp. 86-94.

\section{Style - Harvard Anglia:}

Kiteva Rogleva, N., Gegovska-Zajkova, S. \& Fustik, V., 2014. Leadership skills of the young professionals in industry and other institutions - a case study for master students. MEST Journal, 1507 , 2(2), pp. 86-94.

Style - ISO 690 Numerical Reference:

Leadership skills of the young professionals in industry and other institutions - a case study for master students. Kiteva Rogleva, Nevenka, Gegovska-Zajkova, Sonja and Fustik, Vangel. [ed.] Zoran Čekerevac. 2, Belgrade : MESTE, 07 15, 2014, MEST Journal, Vol. 2, pp. 86-94. 